Article

\title{
Individual Differences, Self-Efficacy, and Chinese Scientists' Industry Engagement
}

\author{
Zhiyan Zhao * (1) and Jianfeng Cai \\ School of Management, Northwestern Polytechnical University, Xi'an 710072, Shaanxi, China; \\ caijf@nwpu.edu.cn \\ * Correspondence: xyzhao829@gmail.com
}

Received: 18 October 2017; Accepted: 1 December 2017; Published: 8 December 2017

\begin{abstract}
Research indicates that non-commercial and informal university-industry interactions, which are defined as academic engagement, account for a larger part and play a more important role than commercialization in academic knowledge transfer in China. This paper aims to explore the effect of Chinese scientists' individual differences on academic engagement via social cognitive theory. This study attempts to provide an interpretation of how individual differences affect Chinese academics' industrial engagement through self-efficacy. Based on data collection from Chinese universities, these analysis results show that gender, academic rank, industry connections, and previous industrial experience are significantly associated with Chinese scientists' industry engagement. Furthermore, a scientist's self-efficacy in industry collaborations is also influenced by these four individual factors. The mediating effects of self-efficacy on the relationship between individual differences and academic engagement are confirmed by empirical analysis results. Implications, limitations, and future research directions are discussed at the end of this paper.
\end{abstract}

Keywords: academic engagement; individual differences; self-efficacy; mediating effect

\section{Introduction}

The mission of universities has transformed from teaching and research to the development of teaching, research, and contributing to national and local economies simultaneously during the last two decades, as a result of global attention on the "entrepreneurial university" [1-3]. The Chinese central government (primarily through the Ministry of Education (MOE)) has introduced many directives to promote economic development through university-based research in the last decade. Specifically, the MOE has put performance of technology transfer into universities assessment criteria in recent years [4]. Following this trend, Chinese universities have begun to encourage scientists to diffuse knowledge through industrial collaborations.

Different channels of university-industry knowledge transfer have been summarized in previous studies. Commercialization, which mainly refers to patenting and academic entrepreneurship, has attracted plenty of scholarly attention $[5,6]$. However, some recent research points out that non-commercial and informal interactions, such as consulting, collaborative research, contract research and other informal collaborations, account for proportionately more in university knowledge transfer [6-10]. These activities are defined as academic engagement [11].

Research has indicated that an extremely small proportion of firms view universities in developing countries as a source of patent applications, core technology, and new products or processes in the environment of economic globalization $[12,13]$. Commercial activities cannot cover the whole picture of academic knowledge diffusion in Chinese universities. To contrast, research shows that a considerable part of firms perceive universities as sources of information rather than a technology source in China $[14,15]$. Information from scientists can boost firms' absorptive capacity or develop innovation capabilities via consulting, contract research, and other informal collaborations $[16,17]$. 
Previous studies on university-industry interactions mainly focused on commercialization. Specifically, demographic characteristics, academic status, experience, and service of technology transfer offices were found to significantly influence academics' commercial activities [18-22]. A small but increasing body of research has examined the influence mechanism of academics' engagement with industry $[6,23,24]$. However, extant research on academic engagement is based on samples in Western countries and can rarely be found within a Chinese context, where socioeconomic and cultural backgrounds are particularly different from Western countries. Typically, in the context of economic globalization, Chinese universities are not considered crucial sources of emerging technology or commercialization [25]. Moreover, the traditional social hierarchy formed by Confucian attitudes and norms means that some scientists' individual factors, such as gender and academic rank, play a significant role when seeking a partner in industry. Additionally, China is a relationship-based society [26]. Previous studies have revealed that "guanxi," which refers to an individual's social connections, plays a remarkable function in China [27]. Therefore, individual factors that reflect a scientist's industrial networks might also affect academic engagement. Considering these differences, this study puts forward gender, academic rank, industrial connection, and previous experience as independent variables, with further examination as to how and why these factors influence academic engagement.

To narrow the above gap, this present study aims to explore the mechanisms of individual differences in academic engagement within a Chinese context and, further, to explain these mechanisms by social cognitive theory. Self-efficacy, which refers to one's belief in one's ability to accomplish a special task, can appropriately capture an individual's psychological changes in action when making decisions [28]. Previous research indicates that self-efficacy is antecedent to an individual's entrepreneurial intention and entrepreneurial activities, and has a mediating role between external culture and a scientist's intention toward industrial engagement [29-31]. Findings from individual's entrepreneurial activities indicate that self-efficacy also could be used to explain the impacts of individual factor on academic engagement. Scientists' individual differences in gender, academic rank and industrial connections probably generate different self-efficacy, further resulting in pronounced differences in academic engagement.

The authors argue that scientists' individual factors will affect academic engagement. Although some Western studies have provided insights into academic engagement, given that an individual's activities might be characterized by their specific social cultural context, findings from Western contexts might not be fully valid for Chinese universities. This study contributes to extant theories on academic engagement by applying social cognitive theory to academic knowledge diffusion.

This paper begins by introducing individual differences in academics' industry engagement, followed by a theoretical development of the mediating effects of self-efficacy between individual differences and academic engagement. Section 4 presents a description of the sample and methodology. Section 5 presents an empirical evaluation of measurement scales and regression results related to the hypothesized relationships. This paper concludes with discussion, implications for academia and practice, and future research.

\section{Individual Differences in Scientists' Industry Engagement}

\subsection{Gender and Academic Engagement}

Women face a specific series of gender-related bias in China, which greatly influences their career development and choices. First, Chinese female scientists face an imbalanced work environment, which probably results in less encouragement to realize career potential. A comparative study found that Chinese females have less job satisfaction than U.S. females [32]. Another study also pointed out that Chinese females are in a work environment of high effort and low reward [33]. Second, Chinese women bear disproportionate domestic duties, which results in tough choices between career and family. Due to the societal history of China, particularly Confucian attitudes and norms, Chinese women were usually 
occupied by heavy domestic duties [34]. Female scientists are also affected by this bias to some extent. A study proved that female scientists with children spend more time on childcare duties and less time on their professional duties than male scientists who also have children [35]. Moreover, female scientists' childbearing ages overlap with key years of scientific research performance [36]. The scientific performance cost to women scientists related to childbirth was reckoned to be two years' worth of publications [36]. Third, Chinese women usually have less access to networking than men, which leads to less advantage for knowledge and resource exchange. Research suggests that females have inequality in networks and social capital in China [37], where social connections are crucial for seeking outside collaborations $[26,27]$. Research also indicates that female scientists have less social capital than male scientists to bridge collaborations with external partners [38].

Gender has been proven to significantly affect an academic's commercial activities in Western countries [39], suggesting that male scientists are more likely to succeed in commercialization. However, little is known about how gender affects scientists' non-commercial and informal industrial activities. The authors expect that Chinese male scientists engage in more industrial activities than their female colleagues for several reasons, considering this analysis. First, in the high effort and low reward environment, female scientists need to pay more time and effort than men to gain contracts with industry sectors. This will inhibit a woman scientist's industry engagement by increasing difficulty. Second, since women scientists usually bear more domestic duties than men, they have less time and attention to give to industrial activities than their male colleagues. Third, a lack of social capital and industrial networks makes it more difficult for female academics to secure resources from industry than males. Thus, the authors hypothesize that:

Hypothesis 1a (H1a). Male academics will be involved in more academic engagement with industry than their female colleagues.

\subsection{Academic Rank and Academic Engagement}

Academic rank appears to have an ambiguous relationship with commercialization in extant research. One side shows that scientists with high academic status are usually considered more scientifically productive than their colleagues, resulting in more resources and capital from industry for them due to their reputation and prestige [11]. Conversely, however, some research indicates that younger academics are more likely to engage in commercialization because young scientists are influenced more by a social environment that considers commercialization to be more legitimate [40].

Despite the ambiguous effect on scientists' commercial activities, the authors expect there to be a positive relationship between academic rank and an academic's engagement with industry for two reasons. First, some senior scientists are unwilling to engage in commercial activities due to their academic role [41]. A considerable number of scientists perceive that commercial activities can hamper their research agenda, in other words. However, a study revealed that scientists collaborate with industry for different reasons; non-commercial activities are motivated by research-related motivations, while patenting and entrepreneurship are informed by economic motivations [42]. Thus, senior scientists who are reluctant to commercialize their research outcome might be willing to become involved in academic engagement. Second, scientists in universities usually self-evaluate and are evaluated by different professional bodies, then receive resources on this basis [43]. Consequently, there is a competitive nature to professional status in academia and this kind of competition is intensified due to the more stringent publications and requirements for promotion [44]. Senior professors usually have a stable income and scientific prestige while engaging in industrial activities [45], yet junior scientists are more concerned about promotion and are unwilling to become involved in knowledge diffusion activities because of the risk of delaying the publication process [46]. Thus, senior scientists are more likely to engage in industrial activities than junior ones.

Hypothesis $\mathbf{1 b} \mathbf{( H 1 b ) . ~ S c i e n t i s t s ' ~ a c a d e m i c ~ r a n k ~ i s ~ p o s i t i v e l y ~ r e l a t e d ~ t o ~ a c a d e m i c ~ e n g a g e m e n t ~ w i t h ~ i n d u s t r y . ~}$ 


\subsection{Industry Connection and Academic Engagement}

Some evidence can be found in prior research about how industrial connections affect university-industry interactions [21]. Affiliation with a research center is related positively to a scientist's industrial involvement [47]. This study expects that Chinese scientists holding industry connections will enhance their engagement with industry for two reasons. First, industry connections provide scientists with more chances to seek contracts with firms by personal contacts. Academic engagement is characterized by inter-organizational collaborations and includes person-to-person interactions $[9,11]$. It can be inferred that industry connections play a crucial role in scientists' engagement with industrial partners, from this viewpoint. Second, a Chinese cultural context probably amplifies the function of an industry connection in academics' engagement with industry. Connection, which is called "guanxi" in the literature, performs a critical function in Chinese social life [27,48]. Industrial connections represent a quite important part of an individual's social capital in China [49]. Thus, Chinese scientists holding industrial connections find it easier to build ties with industrial sectors.

Given the crucial function of connection for academic engagement and the relationship-based context in China, this study hypothesizes that:

Hypothesis 1c (H1c). Having an industry connection is positively related to academics' engagement with industry.

\subsection{Previous Industry Experience and Academic Engagement}

Previous research shows that industrial experience has a positive effect on academics' commercial activities [21,50]. Little is known, however, about the effect of prior industrial experience on academic engagement, especially in China. It is expected that previous experience is positively related to Chinese academics' engagement with industry. This is partly because previous experience likely affects an academic's attitude toward academic engagement. Specifically, scientists who have engaged in industrial activities before will have a greater belief in collaboration with industry, irrespective of the outcome of the previous one [50]. An early study also provides evidence that industrial experience is related positively to industrial activities [51]. Moreover, experienced scientists are more likely to engage in greater networking with industrial sectors. Scientists who have industrial networks could exploit their networking advantages to gain more contracts than those who do not have such resources. Combining this concept with the unique cultural context in China, the authors hypothesize that:

Hypothesis 1d (H1d). Previous industrial experience in university-industry interaction is positively related to academic engagement with industry.

\section{Self-Efficacy and Individual Differences in Academic Engagement}

\subsection{Individual Differences and Self-Efficacy}

According to social cognitive theory, self-efficacy is a person's belief about their ability to do something, and it is formed by four sources of information: "performance accomplishments, vicarious experience, persuasion, and physiological states" (Bandura, 1977, p. 5). Particularly, scientists' individual differences, which are gender, academic rank, industry connections, and previous experience, could influence their self-efficacy beliefs in academic engagement through psychological changes due to these four aspects.

Gender might affect scientists' self-efficacy through performance accomplishments, vicarious experience, verbal persuasion, and physiological states. Due to the strongly male-dominated societal context in China, Chinese female scientists often lack encouragement to engage in industry projects. Earlier research attested that male university students had stronger beliefs than their women schoolmates regarding their commercial activities [52]. Thus, female scientists likely feel less valued for academic engagement than males. Moreover, traditional Chinese gender stereotypes 
and disproportionate household duties could cause women more adverse emotions such as anxiety and fear, resulting in lower self-efficacy. Social comparison theory indicates that people try to emulate the activities of their peers who are in similar conditions. Specifically, academics usually conduct their work-related behaviors by comparing themselves with colleagues who have similar attitudes or abilities [53]. Thus, vicarious experience, relying on inferences from social comparison, probably plays a weaker role in improving women's self-efficacy.

Academic rank is also likely to significantly affect scientists' self-efficacy. Senior scientists have better performance than their juniors in terms of scientific accomplishments, which often strengthens their beliefs in their abilities in other activities. Social cognitive theory states that successful performance can increase an individual's self-efficacy through a psychological change [28]. Accordingly, senior academics probably have more self-confidence in industrial activities than juniors. Meanwhile, according to social comparison theory, people tend to compare their activities with those who have a similar academic rank, indicating that seniors probably hold more self-efficacy beliefs due to vicarious experience and verbal persuasion from their peers. Likewise, the confidence accumulated by scientific accomplishments could effectively inhibit aversive emotional arousal.

Possessing industry connections also seems to be conducive to enhancing a scientist's self-efficacy in industrial activities., Connections play an extremely important role in Chinese society [48]. Scientists with an extra position in industry likely have enhanced self-confidence through performance accomplishments. Furthermore, industry connections usually provide a scientist with vicarious experiences and verbal suggestions from their industrial partners. Familiarity with an industrial environment could also help academics to control unfavorable emotions.

Previous experience with industry appears to positively affect scientists' academic engagement. Experience is generally associated with one's belief in one's skills in a particular domain [50]. Successful experiences strengthen belief in self-worth by direct performance accomplishments [28]. Moreover, the social learning theory suggests that even negative experiences can be very intense learning events that might have the same effect as positive ones [54]. Once a person engages in an activity, the chances are that his/her confidence in subsequent engagement will be high, regardless of the results of the initial experience. Vicarious experience and verbal persuasion can also be gained from previous interactions and industrial colleagues. Anxiety and fear could be controlled and avoided by accumulated experience.

The above analysis allows the authors to hypothesize as follows:

Hypothesis 2a (H2a). Male scientists will have more self-efficacy than their female colleagues in academic engagement.

Hypothesis $\mathbf{2 b} \mathbf{( H 2 b ) . ~ S e n i o r ~ s c i e n t i s t s ~ w i l l ~ h a v e ~ m o r e ~ s e l f - a s s u r a n c e ~ t h a n ~ j u n i o r ~ o n e s ~ i n ~ a c a d e m i c ~ e n g a g e m e n t . ~}$

Hypothesis 2c (H2c). Scientists with industry connections will have more self-confidence than others in academic engagement.

Hypothesis 2d (H2d). Scientists holding industrial experience will have more self-efficacy than others in academic engagement.

\subsection{Self-Efficacy and Academics' Engagement with Industry}

Bandura provided microanalyses that supported the relationship between perceived self-efficacy and behavioral changes [28]. Since then, plenty of studies have examined how self-efficacy influences individuals' actions in various fields. Some scholars revealed that creative self-efficacy positively influences an individual's creative behaviors $[55,56]$. Regarding university-industry interaction, college students with high creative self-efficacy facilitate their creative practice [57]. Entrepreneurial self-efficacy was proven to have a positive relationship with scientists' entrepreneurial intention $[31,58]$ 
and commercialization behaviors [59]. Social cognitive theory indicates that self-efficacy affects not only scientists' effort and persistence in industrial collaborations, but also their choices of industrial activities. Therefore, scientists with high self-efficacy expectations are more likely to engage in academic engagement within industrial sectors. Combining the link between individual factors and self-efficacy is discussed in Section 2, where it is further assumed that individual factors will indirectly influence academic engagement via self-efficacy. Thus, the authors hypothesize:

Hypothesis 3 (H3). Scientists' self-efficacy is positively related to their engagement with industry.

Hypothesis 4 (H4). Self-efficacy mediates the relationship between individual factors and academics' engagement with industry.

Figure 1 presents the theoretical framework of this paper.

Individual differences

(i) Gender

(ii) Academic rank

(iii) Industry connection

(iv) Industrial experience

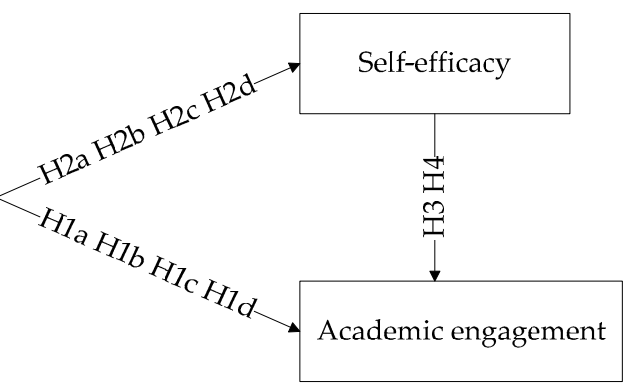

Figure 1. Theoretical framework.

\section{Methodology}

\subsection{Sampling and Data Collection}

The sample for this study was the population of researchers in Chinese universities, and was collected from March to July 2016. Respondents were chosen from the list of universities published by the Ministry of Education of China [60]. Given the huge population of researchers in China, universities in Shaanxi province were mainly chosen as the sample due to the abundant and comprehensive higher education resources there. Moreover, because this research was aimed at scientists who engage in teaching, research, and industrial activities, the target population excluded post-doctorates, technicians, etc. Different levels of higher education institutions, including the "985" and "211" Projects, key universities, ordinary universities, private colleges, and specialized colleges, were involved in this survey. (The "985" Project was initiated in 1998 by the Chinese central government and aimed to transform top Chinese universities into world-class universities. The "211" Project refers to universities that the Chinese government plans to develop in the 21st century. Key universities are recognized as prestigious and receive a high level of support from the Chinese central government. Ordinary universities are other universities that are funded by the government and award bachelor degrees. Private colleges are colleges that are funded by private funds. Specialized colleges are institutes that can only grant college degrees.) Most of the data was collected through an online questionnaire and a small part was collected offline. The questionnaire was designed by measurements developed by previous studies. A few questions were adjusted to avoid conceptual vagueness and item ambiguity.

The survey proceeded in two phases. First, a pilot survey was conducted in a group of 50 researchers. This step aimed at researching the questionnaire itself. Invitations to participate in the survey were sent via email. Face-to-face interviews were adopted in a few instances to consult about suggested modifications to the questionnaire. Second, extensive invitations were sent through e-mail addresses that were collected from the official websites of respondents' universities. A reminder email was sent if a respondent did not answer within one week. Additionally, for the purposes of ensuring 
the diversity of the sample, the study was conducted by the following steps: the participation request was only sent to 10 members in one department first; another 10 requests in the same department were sent if there was no response within a week; the above two procedures were repeated until at least five responses were received or all members in the department had received a request. Finally, 564 complete questionnaires were returned, and the valid usable return rate was about $9.7 \%$. The valid response rate was low for two reasons. The authors obtained 723 failure messages, suggesting that e-mail addresses were invalid or e-mails could not be sent. Additionally, 418 incomplete responses were removed.

Analysis results of the T-tests showed that there were no significant differences $(p \geq 0.05)$ between completed and uncompleted responses, or early and late respondents in terms of gender, academic rank, industry connection, and previous experience, which indicated that non-response bias was unlikely to be a problem in this sample [61].

\subsection{Measures}

\subsubsection{Dependent Variables}

The authors utilized two methods to measure dependent variables in this study to cover the depth and breadth of academic engagement. The first measurement, which was developed by Bozeman and Gaughan [62], examined the degree of a scientist's industrial engagement by constructing an academic engagement index. The questionnaire asked respondents the frequency of 11 types of academic engagement activities from the beginning of 2014 to the end of 2015, with five interval options: 0 times; 1-2 times; 3-5 times; $6-9$ times; and above 10 times [6]. The academic engagement index was calculated via the following steps:

First, the degree of difficulty of each type of engagement activity was computed (see Table 1). The difficulty degree demonstrated the proportion of respondents who did not engage this kind of activity in 2014 and 2015. It was calculated as follows:

$$
d_{j}=1-\frac{\sum_{n=1}^{N} b_{n, j}}{N}
$$

where $j=1 \cdots 11$ was the type of engagement; $N$ was the size of the sample, which was 564 in this study; $b_{n, j}(0=$ no, $1=$ yes $)$ meant whether the $n$th researcher had engaged in the $j$ th type of engagement.

Table 1. Academic engagement activities and difficulty degree.

\begin{tabular}{|c|c|c|}
\hline \multicolumn{2}{|r|}{ How Frequently Have You Been Engaged in the Following Types of Activities in 2014 and 2015? } & \multirow{2}{*}{$\begin{array}{c}\text { Difficulty Degree } \\
0.213\end{array}$} \\
\hline 1. & $\begin{array}{l}\text { A new joint research agreement sponsored by industry (original research work undertaken by } \\
\text { both partners) }\end{array}$ & \\
\hline 2. & $\begin{array}{l}\text { A new joint research agreement sponsored by a third party (original research work undertaken } \\
\text { by both partners) }\end{array}$ & 0.436 \\
\hline 3. & Work with industry personnel that resulted in a patent or copyright & 0.628 \\
\hline 4. & A new consultancy agreement (no original research undertaken) & 0.298 \\
\hline 5. & Secondment to industry (short- or long-term) & 0.543 \\
\hline 6. & Training of company employees (through course enrollment or temporary personnel exchanges) & 0.498 \\
\hline 7. & Postgraduate training in the company (e.g., joint supervision of PhDs) & 0.417 \\
\hline 8. & A new contract research agreement (original research work done by the University alone) & 0.418 \\
\hline 9. & $\begin{array}{l}\text { Creation of new physical facilities with industry funding (e.g., new laboratory, other building } \\
\text { on campus) }\end{array}$ & 0.640 \\
\hline 10. & Attendance at conferences with industry and university participation & 0.324 \\
\hline 11. & Attendance at industry-sponsored meetings & 0.427 \\
\hline
\end{tabular}

Source: D'Este and Patel (2007). 
Then, an academic engagement index was computed as follows:

$$
E_{n}=\sum_{j=1}^{11} d_{j} T_{j}
$$

where $T_{j}$ meant the average of all interval options, which were $0,1.5,4,7.5$, and 10 , respectively; $d_{j}$ was the difficulty degree mentioned in the first step.

The value range of academic engagement in the sample was from 0 to 36.29. The authors used an alternative measurement of academic engagement for a robustness check. An integer variable for each of the samples was used to capture the additive count of respondents' engagement in 11 types of industrial activities. This measurement covered the breadth of scientists' industrial activities, with the range being from 0 to 11 .

\subsubsection{Independent Variables}

The authors used a series of variables to capture academics' individual differences in industrial activities based on previous studies. Gender was measured by a dummy variable in which women were coded 0 and men were 1 . Research on the academics' commercial activities indicated that male scientists collaborated more with industry sectors than did female scientists [39]. Academic rank, which represented scientists' scientific performance, was measured by their academic title $(0=$ assistant or lecturer, 1 = associate professor or professor). Industry connection was measured by a dummy variable by identifying whether respondents held a secondary position in industry sectors $(0=$ no, $1=$ yes $)$. Previous industrial experience was measured through a five-point Likert scale. Respondents were asked whether they believed they had rich industrial working experience before 2014. This variable ranged from " $1=$ totally disagree" to " $5=$ totally agree."

\subsubsection{Mediator Variables}

Self-efficacy was defined as people's belief in their capability to perform a task, and it is argued that it could be a set of interrelated tasks $[54,63]$. Therefore, we measured scientists' self-efficacy in industrial engagement by using the specific types of academic engagement, which were consulting, contract research, joint research, and network building between scientists and industrial sectors [23]. This study measured self-efficacy by asking responders how confident they were in consulting, contract research, joint research and network building activities (see Appendix A). Each item was associated with a 5 -point Likert scale, ranging from " $1=$ totally disagree" to " $5=$ totally agree".

\subsubsection{Control Variable}

To control for academics' discipline information, the study included the academic field in this research. Academic field was measured by a dummy variable in which applied disciplines were coded 1 and basic disciplines were coded 0 .

\section{Results}

\subsection{Empirical Evaluation of the Measurement Scales}

This study used SPSS 22 for descriptive statistical analysis. The reliability of measurement scales was measured by internal consistency, which was estimated by Cronbach's Alpha [64]. The EFA was analyzed to test the fundamental structures of scales [65]. Tables 2 and 3 provide the technical details of variable constructions. Table 2 shows the means, standard deviations, and correlation matrices of all variables. This sample consisted of 564 respondents from Chinese universities: $62 \%$ of them were male and $56 \%$ had an associate professor or professor title; $24 \%$ had a position in industry departments. The detailed results of the reliability analysis of self-efficacy was performed by SPSS 22, as shown in Table 3, and showed that Cronbach's Alpha for the scales of self-efficacy was 0.924, indicating 
reliable scales. The results of the EFA suggested that the scale of KMO was 0.849 , and STATISTICALLY significant, as expected.

Table 2. Descriptive statistics and correlations.

\begin{tabular}{|c|c|c|c|c|c|c|c|c|c|c|}
\hline \multirow{2}{*}{ Variables } & \multirow{2}{*}{ Mean } & \multirow{2}{*}{$\begin{array}{l}\text { Standard } \\
\text { Deviation }\end{array}$} & \multicolumn{6}{|c|}{ Correlation Matrix } & \multirow[b]{2}{*}{ (7) } & \multirow[b]{2}{*}{ (8) } \\
\hline & & & (1) & (2) & (3) & (4) & (5) & (6) & & \\
\hline (1) Academic field & 0.62 & 0.487 & 1.00 & & & & & & & \\
\hline (2) Gender & 0.62 & 0.49 & 0.06 & 1.00 & & & & & & \\
\hline (3) Academic rank & 0.56 & 0.50 & 0.03 & 0.22 ** & 1.00 & & & & & \\
\hline (4) Industry connection & 0.24 & 0.43 & $0.08^{*}$ & 0.14 ** & 0.03 & 1.00 & & & & \\
\hline (5) Previous experience & 3.17 & 1.05 & 0.01 & 0.03 & $0.10^{*}$ & $0.22 * *$ & 1.00 & & & \\
\hline (6) Self-efficacy & 3.24 & 0.93 & 0.03 & $0.18^{* *}$ & $0.27^{* *}$ & 0.23 ** & $0.26 * *$ & 1.00 & & \\
\hline (7) Academic engagement index & 8.59 & 8.33 & $0.12^{* *}$ & 0.22 ** & 0.36 ** & $0.31^{* *}$ & 0.18 ** & $0.40^{* *}$ & 1.00 & \\
\hline (8) Academic engagement II & 6.16 & 3.89 & $0.10^{*}$ & 0.27 ** & $0.53 * *$ & 0.24 ** & 0.14 ** & 0.44 ** & $0.81^{* *}$ & 1.00 \\
\hline
\end{tabular}

Table 3. Reliability and validity analysis of self-efficacy.

\begin{tabular}{|c|c|c|c|c|c|c|c|}
\hline \multirow{2}{*}{ Variables Items } & \multirow{2}{*}{$\begin{array}{l}\text { Factorial } \\
\text { Analysis }\end{array}$} & \multicolumn{2}{|c|}{ Reliability } & \multicolumn{4}{|c|}{ Correlations } \\
\hline & & Cronbach & Item to Total & SE1 & SE2 & SE3 & SE4 \\
\hline $\begin{array}{l}\text { SE1: confidence in joint research } \\
\text { SE2: confidence in contract research } \\
\text { SE3: confidence in consulting } \\
\text { SE4: confidence in network building }\end{array}$ & $\begin{array}{l}\text { KMO } 0.849 \\
\chi^{2} 1733.389 \\
\text { Sig. }\end{array}$ & 0.924 & $\begin{array}{l}0.808^{* * * *} \\
0.846^{* * *} \\
0.848^{* * * *} \\
0.796^{* * *}\end{array}$ & $\begin{array}{l}1.000 \\
0.781^{* * *} \\
0.764^{* * *} \\
0.684^{* * *}\end{array}$ & $\begin{array}{c}1.000 \\
0.779^{* * *} \\
0.748^{* * * *}\end{array}$ & $\begin{array}{c}1.000 \\
0.766^{* * *}\end{array}$ & 1.000 \\
\hline
\end{tabular}

\subsection{Regression Results of Hypotheses}

Table 4 provides the results of seven regression models performed by SPSS 22. For Model 1 the authors analyzed the effect of individual variables on academic engagement. Model 2 was to test individual variable impacts on self-efficacy. Model 3 considered the influence of self-efficacy on academic engagement. Models $4-7$ were for the moderating effect of self-efficacy on individual factors. A control variable was put into each model. The authors utilized centering to control multicollinearity problems. Additionally, variance inflation factors (VIF) were computed in each model, with the results showing that all of the VIFs were below the critical value of 5; thus, there was no multicollinearity problem in this study [61].

Model 1 presents the effects of individual factors on academic engagement. Academic field was positively associated with academic engagement in each model, which indicates that scientists in applied disciplines were more likely to engage in industrial activities than those in basic disciplines. Results show that gender had a significant and positive impact on academic engagement, which is in line with previous research on university-industry interaction [62] and indicates that male scientists were involved in more industrial activities than were female scientists. Hypothesis 1a is supported. Academic rank had a positive and statistically significant effect on academic engagement, agreeing with previous studies [24] and suggesting that senior scientists engaged in more collaborations with industry sectors. Thus, Hypothesis $1 \mathrm{~b}$ is supported. Holding an extra position in industrial sectors was also proven to be positively and significantly related to academic engagement, indicating that an external position strengthened a scientist's ability to search for contracts with industry through personal networking. Hypothesis $1 \mathrm{c}$ is supported. Previous industrial experience had a positive and significant effect on academic engagement, suggesting that experienced scientists engaged in more industrial activities through networks accumulated in previous collaborations. Thus, Hypothesis $1 \mathrm{~d}$ is supported.

Model 2 shows the effect of individual factors on a scientist's self-efficacy in industry engagement. Gender was positively and statistically significantly connected with self-efficacy, indicating that male scientists held more confidence in industrial activities than did female scientists. Hypothesis $2 \mathrm{a}$ is supported. Academic rank had a positive and significant relationship with self-efficacy, suggesting 
that senior scientists had more confidence in performing collaborative projects with industry than did junior scientists. Thus, Hypothesis $2 b$ is supported. Having an extra position in industrial sectors was positively and statistically significantly related to self-efficacy, indicating that scientists with an external position were likely more familiar with an industrial environment and, thus, had more belief in their ability to perform industrial activities well. Hypothesis $2 \mathrm{c}$ is supported. Previous experience had a positive and significant effect on self-efficacy, suggesting that industrial experience enhanced a scientist's efficacy through performance accomplishments. Thus, Hypothesis $2 \mathrm{~d}$ is supported.

Table 4. Regression results. Dependent variables: self-efficacy and academic engagement index.

\begin{tabular}{|c|c|c|c|c|c|c|c|}
\hline \multirow{2}{*}{ Variables } & \multirow{2}{*}{$\begin{array}{c}\text { Self-Efficacy } \\
\text { Model } 2 \\
\end{array}$} & \multicolumn{6}{|c|}{ Academic Engagement } \\
\hline & & Model 1 & Model 3 & Model 4 & Model 5 & Model 6 & Model 7 \\
\hline Academic field & $\begin{array}{c}0.013 \\
(0.074)\end{array}$ & $\begin{array}{l}1.460 * \\
(0.634)\end{array}$ & $\begin{array}{l}1.825^{* *} \\
(0.657)\end{array}$ & $\begin{array}{l}1.698^{* *} \\
(0.649)\end{array}$ & $\begin{array}{l}1.753^{* *} \\
(0.631)\end{array}$ & $\begin{array}{l}1.561 * \\
(0.641)\end{array}$ & $\begin{array}{l}1.828^{* *} \\
(0.655)\end{array}$ \\
\hline Gender & $\begin{array}{l}0.186^{*} \\
(0.076)\end{array}$ & $\begin{array}{l}1.916^{* *} \\
(0.654)\end{array}$ & & $\begin{array}{c}2.601^{* * *} \\
(0.660)\end{array}$ & & & \\
\hline Academic Rank & $\begin{array}{c}0.421^{* * *} \\
(0.074)\end{array}$ & $\begin{array}{c}5.277^{* * *} \\
(0.637)\end{array}$ & & & $\begin{array}{c}4.473 * * * \\
(0.643)\end{array}$ & & \\
\hline Position & $\begin{array}{c}0.362 * * * \\
(0.088) \\
\end{array}$ & $\begin{array}{c}4.926^{* * *} \\
(0.752)\end{array}$ & & & & $\begin{array}{c}4.245^{* * *} \\
(0.756) \\
\end{array}$ & \\
\hline Experience & $\begin{array}{c}0.177^{* * *} \\
(0.035)\end{array}$ & $\begin{array}{l}0.729^{*} \\
(0.300)\end{array}$ & & & & & $\begin{array}{c}0.654 \\
*(0.313)\end{array}$ \\
\hline Self-efficacy & & & $\begin{array}{c}3.588^{* * *} \\
(0.344)\end{array}$ & $\begin{array}{c}3.351 * * * \\
(0.345)\end{array}$ & $\begin{array}{c}2.941 * * * \\
(0.343)\end{array}$ & $\begin{array}{c}3.141^{* * *} \\
(0.345)\end{array}$ & $\begin{array}{c}3.393 * * * \\
(0.356)\end{array}$ \\
\hline Constant & $\begin{array}{c}2.232 * * * \\
(0.131)\end{array}$ & $\begin{array}{c}0.057 \\
(1.122)\end{array}$ & $\begin{array}{c}-4.163 * * \\
(1.217)\end{array}$ & $\begin{array}{c}-4.925^{* * *} \\
(1.217)\end{array}$ & $\begin{array}{c}-4.543 * * * \\
(1.170)\end{array}$ & $\begin{array}{c}-3.551^{* *} \\
(1.190)\end{array}$ & $\begin{array}{c}-5.605^{* * *} \\
(1.396)\end{array}$ \\
\hline Adjusted $R^{2}$ & 0.162 & 0.234 & 0.171 & 0.192 & 0.236 & 0.214 & 0.176 \\
\hline Observations & 564 & 564 & 564 & 564 & 564 & 564 & 564 \\
\hline
\end{tabular}

Model 3 presents the effect of scientists' self-efficacy on academic engagement. Results show that self-efficacy had a positive and statistically significant effect on academic engagement, indicating that scientists with stronger beliefs in industrial collaboration presented more industrial behaviors. Thus, Hypothesis 3 is supported.

This paper tested mediating effects by the method introduced by Baron and Kenny [66]. Models 4-7 present the test results of mediating effects of self-efficacy. Model 4 has self-efficacy and gender added in at the same time, with the result showing that the two variables had a positive and statistically significant effect on academic engagement. Combining the results of Model 1 and Model 2, it can be concluded that self-efficacy had a partial mediating effect on the relationship between gender and academic engagement. Similarly, Model 5 shows that academic rank and self-efficacy were both positively related to academic engagement. Thus, self-efficacy had a partial effect on the relationship between academic rank and academic engagement. Model 6 denotes the partial mediating of self-efficacy on the impact of external position on academic engagement. Model 7 shows that previous experience and self-efficacy were both positively and statistically significantly related to academic engagement. Thus, self-efficacy had a mediating effect on the relationship between previous experience and academic engagement. Hence, self-efficacy had mediating effects on the impact of all individual factors on academic engagement. Hypothesis 4 is supported.

The authors used an alternative measurement of academic engagement, mentioned in Section 4 , to check for the robustness of all models. Since the alternative measurement represented the number of types of scientists engaged in industry activities, the Poisson regression model was used for further analysis. Results generated by Stata 13 show that the main results remained true (see Table 5). Regarding the robustness result, Model 7 shows that when previous experience and self-efficacy are both put in, the effect of previous experience on academic engagement was no longer significant, 
indicating that self-efficacy had a complete mediating effect on the relationship between previous experience and academic engagement.

Table 5. Poisson regression results for robustness check.

\begin{tabular}{|c|c|c|c|c|c|c|c|}
\hline \multirow{2}{*}{ Variables } & \multirow{2}{*}{$\begin{array}{c}\text { Self-Efficacy } \\
\text { Model } 2\end{array}$} & \multicolumn{6}{|c|}{ Academic Engagement II } \\
\hline & & Model 1 & Model 3 & Model 4 & Model 5 & Model 6 & Model 7 \\
\hline Academic field & $\begin{array}{c}0.013 \\
(0.074)\end{array}$ & $\begin{array}{l}0.086^{*} \\
(0.036)\end{array}$ & $\begin{array}{l}0.116^{* *} \\
(0.035)\end{array}$ & $\begin{array}{l}0.105^{* *} \\
(0.035)\end{array}$ & $\begin{array}{l}0.104^{* *} \\
(0.035)\end{array}$ & $\begin{array}{l}0.098^{* *} \\
(0.036)\end{array}$ & $\begin{array}{l}0.115^{* *} \\
(0.035)\end{array}$ \\
\hline Gender & $\begin{array}{l}0.186^{*} \\
(0.076)\end{array}$ & $\begin{array}{c}0.170 * * * \\
(0.038)\end{array}$ & & $\begin{array}{c}0.256^{* * *} \\
(0.038)\end{array}$ & & & \\
\hline Academic Rank & $\begin{array}{c}0.421 * * * \\
(0.074)\end{array}$ & $\begin{array}{c}0.676^{* * *} \\
(0.039)\end{array}$ & & & $\begin{array}{c}0.615^{* * *} \\
(0.039)\end{array}$ & & \\
\hline Position & $\begin{array}{c}0.362 * * * \\
(0.088)\end{array}$ & $\begin{array}{c}0.257^{* * *} \\
(0.039)\end{array}$ & & & & $\begin{array}{c}0.184^{* * *} \\
(0.038)\end{array}$ & \\
\hline Experience & $\begin{array}{c}0.177^{* * *} \\
(0.035)\end{array}$ & $\begin{array}{l}0.028+ \\
(0.017)\end{array}$ & & & & & $\begin{array}{c}0.019 \\
(0.017)\end{array}$ \\
\hline Self-efficacy & & & $\begin{array}{c}0.305^{* * *} \\
(0.019)\end{array}$ & $\begin{array}{c}0.281^{* * *} \\
(0.019)\end{array}$ & $\begin{array}{c}0.230^{* * *} \\
(0.020)\end{array}$ & $\begin{array}{c}0.284^{* * *} \\
(0.019)\end{array}$ & $\begin{array}{c}0.300 \text { *** } \\
(0.019)\end{array}$ \\
\hline Constant & $\begin{array}{c}2.232 * * * \\
(0.131)\end{array}$ & $\begin{array}{c}1.053^{* * *} \\
(0.067)\end{array}$ & $\begin{array}{c}0.717^{* * * *} \\
(0.071)\end{array}$ & $\begin{array}{c}0.637^{* * *} \\
(0.073)\end{array}$ & $\begin{array}{c}0.579^{* * *} \\
(0.073)\end{array}$ & $\begin{array}{c}0.750 * * * \\
(0.072)\end{array}$ & $\begin{array}{c}0.673^{* * *} \\
(0.081)\end{array}$ \\
\hline Pseudo $\mathrm{R}^{2}$ & 0.162 & 0.137 & 0.078 & 0.091 & 0.151 & 0.084 & 0.078 \\
\hline Observations & 564 & 564 & 564 & 564 & 564 & 564 & 564 \\
\hline
\end{tabular}

\section{Discussion}

Despite plenty of studies that have examined university-industry interactions in Western countries, little has been done in China, especially non-commercial and informal industrial activities. This paper provided evidence that individual factors, specifically gender, academic rank, industry connection, and previous experience, could influence academic engagement through a scientist's self-efficacy. These analyses revealed that individual factors significantly affect Chinese academics' self-efficacy and engagement with industry. Particularly, male scientists have stronger self-efficacy and engage in more industrial activities than do female scientists. Senior scientists are more likely to be involved in industrial collaborations. Similarly, academics with an external position and previous experience are also proven to have more collaborative beliefs and more industrial behaviors. According to the mediating effect testing method [66], self-efficacy was confirmed as having a mediating effect on the relationship between individual factors and an academic's engagement with industry. This research provided novel insight to explain how individual differences influence an academics' engagement with industry through psychological changes based on social cognitive theory. Moreover, it was found that the results of gender and academic rank in this study were in line with previous studies done by Western scholars. This indicates that, even though Chinese universities are different from Western ones in terms of both socioeconomic and cultural context, there are still common patterns in university-industry interactions.

This paper contributes to the extant literature in several ways. First, this study has contributed to the work on non-commercial and informal university-industry interactions in Chinese universities, where these kinds of activities take up quite a large part of university knowledge diffusion but are ignored. The Chinese government has been interested in promoting university academics to collaborate with industry sectors, which can stimulate national and local economic development by university knowledge and technology [25]. This study provides insight to understand the changing psychological processes of Chinese scientists in industry engagement, and contributes to promoting the national strategy. Second, this research provides a broader sight of scientists' activities in university-industry interactions. Most previous studies on university-industry interactions highlight commercialization activities such as academic entrepreneurship and patenting $[7,67,68]$, but commercialization activities 
are only a limited part of university knowledge transfer in the context of economic globalization [69]. The measurements used to measure academic engagement not only capture the types but also the frequency of non-commercial and informal activities. This novel insight brings a whole new understanding of scientists' industrial activities. Third, this study provides empirical evidence of academics' industry engagement from a microscopic perspective. Chinese social and economic environment are greatly different from in the West. Chinese scientists obviously would be characterized by a unique Chinese cultural and political context. This study contributes to the influence mechanism of individual factors on academic engagement within a Chinese context. Fourth, the authors have a new perspective on the effect of individual factors on a scientist's industrial activities based on social cognitive theory. Self-efficacy has been proven to be associated with an individual's behavior change [28]. These results confirm that individual differences can affect an academic's industry activities by their self-efficacy beliefs in industrial projects. This work contributes to the psychological interpretation of how individual factors shape the scientist's industrial behaviors.

This study can also assist with decision-making for policy makers and university managers. First, since gender, academic rank, industry connection, and previous experience significantly influence Chinese academics' engagement with industry, policy makers and university managers should make specific policies for that population participating in fewer industry activities. More specific policies should be made for female scientists, junior scientists, and others who lack experience and industrial networks to boost their contribution to knowledge diffusion, for instance. Second, it was discovered that individual differences affect an academic's engagement with industry through self-efficacy, which is shaped by a series psychological processes. According to social cognitive theory, an academic's self-efficacy in industrial projects could be promoted through participant modeling, verbal persuasion and diminishing emotional arousal. Accordingly, policy makers and university managers need to pay more attention to academics' psychological changes to strengthen their self-efficacy in these four aspects.

\section{Limitation and Further Research}

This study has some limitations, which suggest aspects for future research. First, data collection for this paper was constructed in a Chinese context, but most of the measurements used were developed by Western researchers. Although the semantics of the questionnaire were adjusted to get better adaptation for Chinese scientists, cultural and economic differences might still affect the results. Future research could develop measurements by combining extant mature scales with Chinese unique cultural and political characteristics. Second, the impact of Chinese scientists' individual factors on academic engagement and the mediating effect self-efficacy on them were studied, but individual behaviors are proven to be influenced by multilevel determinants such as research team, department or university factors [70]. Thus, future research could be constructed to explore how other levels of factors affect academic engagement. Third, the authors gave out questionnaires to scientists in various disciplines, but scientists from some subjects like art and language refused to reply to the request for academics in these disciplines in the belief that they have no interactions with the private sector. Future research can examine academics' engagement with industry by archival data rather than survey data, for this reason.

Acknowledgments: The authors would like to express their appreciation to the professors who made suggestions for modification of our questionnaire and all the respondents who filled out our survey. The first author gratefully acknowledges Anders Broström from the economic division of the Royal Institute of Technology (KTH) for his guidance about this research when the author studied in Sweden.

Author Contributions: Zhiyan Zhao and Jianfeng Cai conceived and designed the experiments; Zhiyan Zhao performed the survey; Zhiyan Zhao analyzed the data; Zhiyan Zhao wrote the paper; Jianfeng Cai contributed to text proofreading.

Conflicts of Interest: The authors declare no conflict of interest. The founding sponsors had no role in the design of the study; in the collection, analyses, or interpretation of data; in the writing of the manuscript, and in the decision to publish the results. 


\section{Appendix A}

Table A1. Scale of scientists' self-efficacy in industrial engagement activities.

\begin{tabular}{|c|c|c|c|c|c|}
\hline $\begin{array}{l}\text { How Confident Are You in Successfully Engaging in the Following Collaborations with } \\
\text { Industrial Sectors? (1-5 Denote from Very Unconfident to Very Confident) }\end{array}$ & 1 & 2 & 3 & 4 & 5 \\
\hline \multicolumn{6}{|l|}{ A new consultancy research agreement with no original research undertaken } \\
\hline \multicolumn{6}{|l|}{ A new contract research agreement with original research work done by university alone } \\
\hline A new joint research agreement with original research work done by both partners & & & & & \\
\hline $\begin{array}{l}\text { Networking collaborations, such as networking with partners, attendance at conferences } \\
\text { sponsored by industry or with industry }\end{array}$ & & & & & \\
\hline
\end{tabular}

\section{References}

1. Etzkowitz, H. Research groups as 'quasi-firms': The invention of the entrepreneurial university. Res. Policy 2003, 32, 109-121. [CrossRef]

2. Bercovitz, J.; Feldman, M. Entpreprenerial universities and technology transfer: A conceptual framework for understanding knowledge-based economic development. J. Technol. Transf. 2006, 31, 175-188. [CrossRef]

3. Cohen, W.M.; Florida, R.; Randazzese, L.; Walsh, J. Industry and the academy: Uneasy partners in the cause of technological advance. Chall. Res. Univ. 1998, 171, 59.

4. Tang, M.F. A Comparative Study on the Role of National Technology Transfer Centers in Different Chinese Universities; Georgia Institute of Technology: Atlanta, GA, USA, 2006.

5. O'Shea, R.P.; Allen, T.J.; Morse, K.P.; O'Gorman, C.; Roche, F. Delineating the anatomy of an entrepreneurial university: The massachusetts institute of technology experience. RED Manag. 2007, 37, 1-16.

6. D'Este, P.; Patel, P. University-industry linkages in the UK: What are the factors underlying the variety of interactions with industry? Res. Policy 2007, 36, 1295-1313. [CrossRef]

7. Abreu, M.; Grinevich, V. The nature of academic entrepreneurship in the UK: Widening the focus on entrepreneurial activities. Res. Policy 2013, 42, 408-422. [CrossRef]

8. Caldera, A.; Debande, O. Performance of spanish universities in technology transfer: An empirical analysis. Res. Policy 2010, 39, 1160-1173. [CrossRef]

9. Cohen, W.M.; Nelson, R.R.; Walsh, J.P. Links and impacts: The influence of public research on industrial R\&D. Manag. Sci. 2002, 48, 1-23.

10. Schartinger, D.; Schibany, A.; Gassler, H. Interactive relations between universities and firms: Empirical evidence for Austria. J. Technol. Transf. 2001, 26, 255-268. [CrossRef]

11. Perkmann, M.; Tartari, V.; McKelvey, M.; Autio, E.; Broström, A.; D’Este, P.; Fini, R.; Geuna, A.; Grimaldi, R.; Hughes, A. Academic engagement and commercialisation: A review of the literature on university-industry relations. Res. Policy 2013, 42, 423-442. [CrossRef]

12. Wu, W.; Zhou, Y. The third mission stalled? Universities in china's technological progress. J. Technol. Transf. 2012, 37, 812-827. [CrossRef]

13. Zhou, Y.; Sun, Y.; Wei, Y.H.D.; Lin, G.C.S. De-centering 'spatial fix'-Patterns of territorialization and regional technological dynamism of ict hubs in China. J. Econ. Geogr. 2011, 11, 119-150. [CrossRef]

14. Motohashi, K. China's national innovation system reform and growing science industry linkage. Asian J. Technol. Innov. 2006, 14, 49-65. [CrossRef]

15. Shi, Y.; Ma, M.; Liu, X.; Xie, J. Indigenous innovation capabilities of manufacturing firms in hunan province (Hunan Gongye Qiye Zizhu Chuangxin Nengli Yanjiu). Entrepreneurs 2008, 9, 10-12.

16. Zhou, Y. The making of an innovative region from a centrally planned economy: Institutional evolution in Zhongguancun science park in Beijing. Environ. Plan. A 2005, 37, 1113-1134. [CrossRef]

17. Broström, A.; Lööf, H. What Do We Know about Firms' Research Collaboration with Universities? New Quantitative and Qualitative Evidence; CESIS-Centre of Excellence for Science and Innovation Studies, Royal Institute of Technology: Stockholm, Sweden, 2006.

18. Mckelvey, M.; Ljungberg, D. How public policy can stimulate the capabilities of firms to innovate in a traditional industry through academic engagement: The case of the swedish food industry. RED Manag. 2016. [CrossRef] 
19. Bekkers, R.; Freitas, I.M.B. Analysing knowledge transfer channels between universities and industry: To what degree do sectors also matter? Res. Policy 2008, 37, 1837-1853. [CrossRef]

20. Giuliani, E.; Morrison, A.; Pietrobelli, C.; Rabellotti, R. Who are the researchers that are collaborating with industry? An analysis of the wine sectors in Chile, South Africa and Italy. Res. Policy 2010, 39, 748-761. [CrossRef]

21. Haeussler, C.; Colyvas, J.A. Breaking the ivory tower: Academic entrepreneurship in the life sciences in UK and Germany. Res. Policy 2011, 40, 41-54. [CrossRef]

22. Owen-Smith, J.; Powell, W.W. The expanding role of university patenting in the life sciences: Assessing the importance of experience and connectivity. Res. Policy 2003, 32, 1695-1711. [CrossRef]

23. Sellenthin, M.O. Technology transfer offices and university patenting in Sweden and Germany. J. Technol. Transf. 2009, 34, 603-620. [CrossRef]

24. Tartari, V.; Perkmann, M.; Salter, A. In good company: The influence of peers on industry engagement by academic scientists. Res. Policy 2014, 43, 1189-1203. [CrossRef]

25. Ponomariov, B.L. Effects of university characteristics on scientists' interactions with the private sector: An exploratory assessment. J. Technol. Transf. 2008, 33, 485-503. [CrossRef]

26. Liu, H.; Jiang, Y. Technology transfer from higher education institutions to industry in China: Nature and implications. Technovation 2001, 21, 175-188. [CrossRef]

27. Tsui, A.S.; Farh, J.-L.L. Where guanxi matters: Relational demography and Guanxi in the Chinese context. Work Occup. 1997, 24, 56-79. [CrossRef]

28. Bandura, A. Self-efficacy: Toward a unifying theory of behavioral change. Psychol. Rev. 1977, 84, 191. [CrossRef] [PubMed]

29. Chen, C.C.; Greene, P.G.; Crick, A. Does entrepreneurial self-efficacy distinguish entrepreneurs from managers? J. Bus. Ventur. 1998, 13, 295-316. [CrossRef]

30. Boyd, N.G.; Vozikis, G.S. The influence of self-efficacy on the development of entrepreneurial intentions and actions. Entrep. Theory Pract. 1994, 18, 63.

31. Huyghe, A.; Knockaert, M. The influence of organizational culture and climate on entrepreneurial intentions among research scientists. J. Technol. Transf. 2015, 40, 138-160. [CrossRef]

32. Shaffer, M.A.; Joplin, J.R.; Bell, M.P.; Lau, T.; Oguz, C. Gender discrimination and job-related outcomes: A cross-cultural comparison of working women in the United States and China. J. Vocat. Behav. 2000, 57, 395-427. [CrossRef]

33. Li, J.; Yang, W.; Cheng, Y.; Siegrist, J.; Cho, S.-I. Effort-reward imbalance at work and job dissatisfaction in Chinese healthcare workers: A validation study. Int. Arch. Occup. Environ. Health 2005, 78, 198-204. [CrossRef] [PubMed]

34. Bauer, J.; Feng, W.; Riley, N.E.; Xiaohua, Z. Gender inequality in urban China: Education and employment. Modern China 1992, 18, 333-370. [CrossRef]

35. Mason, M.A.; Goulden, M. Marriage and baby blues: Redefining gender equity in the academy. Ann. Am. Acad. Political Soc. Sci. 2004, 596, 86-103. [CrossRef]

36. Williams, W.M.; Ceci, S.J. When scientists choose motherhood. Am. Sci. 2012, 100, 138-145. [PubMed]

37. Lin, N. Inequality in social capital. Contemp. Sociol. 2000, 29, 785-795. [CrossRef]

38. Lehr, J.L. Athena unbound: The advancement of women in science and technology. Bioscience 2001, 51, 504-509. [CrossRef]

39. Ding, W.W.; Murray, F.; Stuart, T.E. Gender differences in patenting in the academic life sciences. Science 2006, 313, 665-667. [CrossRef] [PubMed]

40. Bercovitz, J.; Feldman, M. Academic entrepreneurs: Organizational change at the individual level. Organ. Sci. 2008, 19, 69-89. [CrossRef]

41. Jain, S.; George, G.; Maltarich, M. Academics or entrepreneurs? Investigating role identity modification of university scientists involved in commercialization activity. Res. Policy 2009, 38, 922-935. [CrossRef]

42. D'este, P.; Perkmann, M. Why do academics engage with industry? The entrepreneurial university and individual motivations. J. Technol. Transf. 2011, 36, 316-339. [CrossRef]

43. Whitley, R. The Intellectual and Social Organization of the Sciences; Oxford University Press on Demand: Oxford, UK, 2000.

44. Wood, F. Factors influencing research performance of university academic staff. High. Educ. 1990, 19, 81-100. [CrossRef]

45. Lam, A. Knowledge networks and careers: Academic scientists in industry-university links. J. Manag. Stud. 2007, 44, 993-1016. [CrossRef] 
46. Thursby, J.G.; Thursby, M.C. Are faculty critical? Their role in university-industry licensing. Contemp. Econ. Policy 2004, 22, 162-178. [CrossRef]

47. Boardman, P.C. Beyond the stars: The impact of affiliation with university biotechnology centers on the industrial involvement of university scientists. Technovation 2008, 28, 291-297. [CrossRef]

48. Gold, T.; Guthrie, D.; Wank, D. Social Connections in China: Institutions, Culture, and the Changing Nature of Guanxi; Cambridge University Press: Cambridge, UK, 2002; Volume 21.

49. Lin, N.; Cook, K.S.; Burt, R.S. Social Capital: Theory and Research; Transaction Publishers: New Brunswick, NJ, USA, 2001.

50. Clarysse, B.; Tartari, V.; Salter, A. The impact of entrepreneurial capacity, experience and organizational support on academic entrepreneurship. Res. Policy 2011, 40, 1084-1093. [CrossRef]

51. Van Dierdonck, R.; Debackere, K.; Engelen, B. University-industry relationships: How does the belgian academic community feel about it? Res. Policy 1990, 19, 551-566. [CrossRef]

52. Scherer, R.F.; Brodzinski, J.D.; Wiebe, F.A. Entrepreneur career selection and gender: A socialization approach. J. Small Bus. Manag. 1990, 28, 37.

53. Festinger, L. A theory of social comparison processes. Hum. Relat. 1954, 7, 117-140. [CrossRef]

54. Bandura, A.; Wessels, S. Self-Efficacy. In Encyclopedia of Human Behavior; Academic Press: New York, NY, USA, 1994.

55. Tierney, P.; Farmer, S.M. Creative self-efficacy development and creative performance over time. J. Appl. Psychol. 2011, 96, 277. [CrossRef] [PubMed]

56. Michael, L.H.; Hou, S.T.; Fan, H.L. Creative self-efficacy and innovative behavior in a service setting: Optimism as a moderator. J. Creat. Behav. 2011, 45, 258-272. [CrossRef]

57. Beghetto, R.A. Creative self-efficacy: Correlates in middle and secondary students. Creat. Res. J. 2006, 18, 447-457. [CrossRef]

58. Zhao, H.; Seibert, S.E.; Hills, G.E. The mediating role of self-efficacy in the development of entrepreneurial intentions. J. Appl. Psychol. 2005, 90, 1265. [CrossRef] [PubMed]

59. Sahlan, S.A.B.; Rahman, N.; Amin, S.B.M. Commercialization behavior among academicians: Personal, environmental and entrepreneurial self-efficacy. Aust. J. Bus. Econ. Stud. 2015, 1, 74-86.

60. The Ministry of Education. China University Science and Technology Annual Report; Higher Education Press: Beijing, China, 2015.

61. Hair, J.F.; Black, W.C.; Babin, B.J.; Anderson, R.E. Multivariate Data Analysis: A Global Perspective; Pearson Education, Inc.: Upper Saddle River, NJ, USA, 2010.

62. Bozeman, B.; Gaughan, M. Impacts of grants and contracts on academic researchers' interactions with industry. Res. Policy 2007, 36, 694-707. [CrossRef]

63. Gist, M.E.; Mitchell, T.R. Self-efficacy: A theoretical analysis of its determinants and malleability. Acad. Manag. Rev. 1992, 17, 183-211.

64. Cronbach, L.J. Coefficient alpha and the internal structure of tests. Psychometrika 1951, 16, 297-334. [CrossRef]

65. Prodan, I.; Drnovsek, M. Conceptualizing academic-entrepreneurial intentions: An empirical test. Technovation 2010, 30, 332-347. [CrossRef]

66. Baron, R.M.; Kenny, D.A. The moderator-mediator variable distinction in social psychological research: Conceptual, strategic, and statistical considerations. J. Personal. Soc. Psychol. 1986, 51, 1173. [CrossRef]

67. Mowery, D.C.; Nelson, R.R.; Sampat, B.N.; Ziedonis, A.A. The growth of patenting and licensing by US universities: An assessment of the effects of the bayh-dole act of 1980. Res. Policy 2001, 30, 99-119. [CrossRef]

68. Geuna, A.; Nesta, L.J.J. University patenting and its effects on academic research: The emerging European evidence. Res. Policy 2006, 35, 790-807. [CrossRef]

69. Agrawal, A.; Henderson, R. Putting patents in context: Exploring knowledge transfer from MIT. Manag. Sci. 2002, 48, 44-60. [CrossRef]

70. Colyvas, J.A.; Powell, W.W. Roads to institutionalization: The remaking of boundaries between public and private science. Res. Organ. Behav. 2006, 27, 305-353. [CrossRef]

(C) 2017 by the authors. Licensee MDPI, Basel, Switzerland. This article is an open access article distributed under the terms and conditions of the Creative Commons Attribution (CC BY) license (http:/ / creativecommons.org/licenses/by/4.0/). 